\title{
Causative Pathological Substances (CPS)
}

Salah Mohamed El Sayed, HS Mahmoud, MMH Nabo

\section{Source}

El Sayed SM Mahmoud HS. (2013). Methods of Wet Cupping Therapy (Al-Hijamah): In Light of Modern Medicine and Prophetic Medicine Altern Integ Med, vol. 02 (03) doi:10.4172/23275162.1000111

Causative Pathological Substances or CPS include both disease-causing substances and disease-related substances resulting during disease pathogenesis.

These authors then referred the CPS in autoimmune diseases, as an example, to autoantibodies, antigen- antibody complexes, inflammatory mediators, prostaglandins, inflammatory cytokines, soluble cytokine receptors, hydrolytic enzymes, ROS and others [T an EM. Autoantibodies, autoimmune disease, and the birth of immune diagnostics. J Clin Invest. 2012 Nov 1; 122(11):3835-6. and Reg inald Gorczynski, Jacqueline Stanley. Clinical Immunology. (1999). Landes Bioscience, 810 S. Church Street, Georgetown, Texas, U.S.A. 78626] 